\title{
Article \\ Effects from Converter Slag and Electric Arc Furnace Slag on Chlorophyll a Accumulation of Nannochloropsis sp.
}

\author{
Tianji Liu, Yitong Wang *D, Junguo Li *, Qing Yu, Xiaoman Wang, Di Gao, Fuping Wang, Shuang Cai \\ and Yanan Zeng *
}

check for

updates

Citation: Liu, T.; Wang, Y.; Li, J.; Yu, Q.; Wang, X.; Gao, D.; Wang, F.; Cai, S.; Zeng, Y. Effects from Converter Slag and Electric Arc Furnace Slag on Chlorophyll a Accumulation of Nannochloropsis sp. Appl. Sci. 2021, 11, 9127. https://doi.org/ 10.3390/ app11199127

Academic Editors: Daria Shi and Sébastien Jubeau

Received: 20 August 2021

Accepted: 23 September 2021

Published: 30 September 2021

Publisher's Note: MDPI stays neutral with regard to jurisdictional claims in published maps and institutional affiliations.

Copyright: (c) 2021 by the authors. Licensee MDPI, Basel, Switzerland. This article is an open access article distributed under the terms and conditions of the Creative Commons Attribution (CC BY) license (https:// creativecommons.org/licenses/by/ $4.0 /)$.
College of Metallurgy and Energy, North China University of Science and Technology, 21 Bohai Street, Tangshan 063210, China; liutianji@ncst.edu.cn (T.L.); qyu0688@gmail.com (Q.Y.); wxiaoman97@gmail.com (X.W.); gaodi1113@gmail.com (D.G.); fwang3692@gmail.com (F.W.); caishuang@ncst.edu.cn (S.C.)

* Correspondence: wangyt@ncst.edu.cn (Y.W.); lijg99@163.com (J.L.); zengyanan@ncst.edu.cn (Y.Z.)

Abstract: The effects of $\mathrm{Ca}^{2+}$ in converter slag and electric arc furnace slag leaching solutions on $\mathrm{CO}_{2}$ content, the effects of $\mathrm{CO}_{2}$ content in solutions on the accumulation of chlorophyll a of Nannochloropsis sp., and the mechanisms were studied. Results showed that addition of $50 \mathrm{mg} / \mathrm{L}$ converter slag leaching solution and $400 \mathrm{mg} / \mathrm{L}$ electric arc furnace slag leaching solution (lower than $50 \mathrm{vol} \%$ concentration) promoted the accumulation of chlorophyll a of Nannochloropsis sp., while an increased concentration of $70 \mathrm{vol} \%$ inhibited its accumulation. The highest concentration of chlorophyll a was obtained on the addition of $10 \mathrm{vol} \%$. With $10 \mathrm{vol} \%$ leaching solutions added, chlorophyll a concentration for converter slag reached $4.2 \mathrm{mg} / \mathrm{L}, 1.45$ times as much as that of pure F/2 medium, and chlorophyll a concentration for electric arc slag reached $3.2 \mathrm{mg} / \mathrm{L}, 1.10$ times as much as that of pure F/ 2 medium. Under the same addition proportion, the promoting or inhibiting effect from converter slag on the accumulation of chlorophyll a of Nannochloropsis sp. was more obvious than that for electric arc furnace slag. The reason for the promotion of chlorophyll a accumulation of Nannochloropsis sp. was that an increase of $\mathrm{Ca}^{2+}$ in the solutions led to an increase of $\mathrm{CO}_{2}$, thereby promoting the photosynthetic rate of microalgae. The study provided new ideas for the green application of solid waste and industrial production of microalgae.

Keywords: leaching solutions; converter slag; electric arc furnace slag; Nannochloropsis sp.; chlorophyll a; $\mathrm{CO}_{2}$ content

\section{Introduction}

Slag is a kind of solid waste produced during the process of steelmaking, composed of slagging material, smelting reactant, eroding and shedding furnace body and fettling materials, impurity substances brought in by metal charge, and slagging materials, which are added on purpose to adjust properties of slag [1]. According to steel making technology, slag can be divided into converter slag, electric arc furnace slag (EAF slag), and open hearth furnace slag [2]. According to the world steel statistics in 2021 from the World Steel Association, the world output of crude steel reached 1.878 billion tons in 2020, in which converter crude steel accounted for $73.2 \%$ and EAF slag accounted for $26.3 \%$. Producing 1 ton of crude steel would produce $10-15 \%$ of slag [3]. Piling up was the main disposal method of slag, which not only occupied a lot of land resources, but also heavy metal elements in slag might dissolve out and enter soil and water bodies because of rainwater leaching, threatening the ecological environment and human health [4]. Currently, the modes of resource utilization of slag mainly include their use in the preparation of steel slag cement $[5,6]$, building materials $[7,8]$, ceramic material $[9,10]$, absorption materials of $\mathrm{CO}_{2}$, and so on $[11,12]$. However, because of problems of large fluctuation, poor activity, poor grindability, and poor stability of slag, the utilization rate of slag in all the countries in the world, especially in developing countries, is still at a low level. 
Generally speaking, microalgae refer to a kind of microorganism with microscopic size, rich nutrition, and high photosynthetic utilization degree, widely living in sea and on land [13]. Microalgae, which is easy to cultivate, has features of wide variety, wide distribution, strong adaptability to environment, short growth cycle, and high absorption of $\mathrm{N}$ and P [14]. Microalgae, not competing with agriculture for land, could grow on wasteland and beach land, and biomass yield per unit area was several times as much as that of higher plants [15]. Currently, microalgae are mainly used in medical food [16], renewable energy [17], wastewater purification [18], and other areas. The main chemical elements of slag include $\mathrm{CaO}, \mathrm{SiO}_{2}, \mathrm{MgO}, \mathrm{Al}_{2} \mathrm{O}_{3}, \mathrm{FeO}$, and so on [19]. Microalgae contain several kinds of nutrient elements that are necessary for the growth of microalgae, such as $\mathrm{Fe}, \mathrm{P}, \mathrm{Si}$, $\mathrm{Ca}, \mathrm{Mg}$, and so on. Thus, slag can provide necessary nutrition for the growth of microalgae. Using slag to cultivate microalgae can not only reduce the cost of culturing microalgae but also relieve substantial stacking of slag. According to reports of Nakamura et al. [20], if an appropriate proportion of $\mathrm{Fe}, \mathrm{Si}, \mathrm{P}$, and $\mathrm{N}$ were added into seawater, some types of phytoplankton would grow quite fast. Because of the low cost, sufficient quantity, sufficient mineral concentration, and ionic properties, slag is the best source of this kind of mineral. Table 1 lists the best growth condition of different types of microalgae. Researchers have found that when relatively low concentration of slag or leaching solution of slag was added into an aquatic environment, the kinds of microalgae whose growth could be promoted were Thalassiosira guillardii (the best addition concentration of slag was $33 \mathrm{mg} / \mathrm{L}$ [21]), Chaetoceros gracile (the best addition ratio of leaching solution of slag was $20-40 \%$ [22]), Rhodomonas lens (the best addition ratio of leaching solution of slag was $20-40 \%$ [22]), Emiliania huxleyi (the best addition ratio of leaching solution of slag was $20-40 \%$ [22]), and Chlorella sp. (the best addition concentration of slag $25 \mathrm{mg} / \mathrm{L}$ [23] and the best addition ratio of leaching solution of slag was 30\% [24]). When a relatively high concentration of slag or leaching solution of slag was added into the aquatic environment, the kinds of microalgae whose growth could be promoted were Skeletonema costatum (the best addition concentration of slag was $100 \mathrm{mg} / \mathrm{L}$ [25] and the best addition ratio of leaching solution of slag was $40-80 \%[20,22]$ ), Thalassiosira allenii (the best addition ratio of leaching solution of slag was $40-80 \%$ [22]), Isochrysis galbana (the best addition ratio of leaching solution of slag was 40-80\% [22]), Thalassiosira angulate (the best addition ratio of leaching solution of slag was 100\% [22]) and Amphidinium carterae (the best addition ratio of leaching solution of slag was $100 \%$ [22]). When an arbitrary concentration of slag or leaching solution of slag was added into the aquatic environment, the kinds of microalgae whose growth could be promoted were Dunaliella tertiolecta [22], Tetraselmis tetrathele [22], Synechococcus sp. [22], Desmodesmus subspicatus [26], Chlorella vulgaris [26], Alexandrium tamarense [25], and Nitzschia laevis [27]. Nevertheless, in spite of the research and explorations on the effects of slag on the growth of microalgae, the reason for the influence of steel slag leaching solution on the growth of microalgae was still unclear.

Table 1. The best growth condition of microalgae.

\begin{tabular}{|c|c|c|c|}
\hline Types of Microalgae & Types of Growth Condition & Best Growth Condition & Reference \\
\hline Thalassiosira guillardii & Slag & $33 \mathrm{mg} / \mathrm{L}$ & [21] \\
\hline Chaetoceros gracile & Leaching Solution of Slag & $20 \mathrm{vol} \%-40 \mathrm{vol} \%$ & [22] \\
\hline Rhodomonas lens & Leaching Solution of Slag & $20 \mathrm{vol} \%-40 \mathrm{vol} \%$ & [22] \\
\hline Emiliania huxleyi & Leaching Solution of Slag & $20 \mathrm{vol} \%-40 \mathrm{vol} \%$ & [22] \\
\hline Chlorella sp. & $\begin{array}{c}\text { Slag } \\
\text { Leaching Solution of Slag }\end{array}$ & $\begin{array}{c}25 \mathrm{mg} / \mathrm{L} \\
30 \mathrm{vol} \%\end{array}$ & $\begin{array}{l}{[23]} \\
{[24]}\end{array}$ \\
\hline Skeletonema costatum & $\begin{array}{c}\text { Slag } \\
\text { Leaching Solution of Slag }\end{array}$ & $\begin{array}{c}100 \mathrm{mg} / \mathrm{L} \\
40 \mathrm{vol} \%-80 \mathrm{vol} \%\end{array}$ & $\begin{array}{c}{[25]} \\
{[20,22]}\end{array}$ \\
\hline
\end{tabular}


Table 1. Cont.

\begin{tabular}{|c|c|c|c|}
\hline Types of Microalgae & Types of Growth Condition & Best Growth Condition & Reference \\
\hline Thalassiosira allenii & Leaching Solution of Slag & $40-80 \%$ & [22] \\
\hline Isochrysis galbana & Leaching Solution of Slag & $40-80 \%$ & {$[22]$} \\
\hline Thalassiosira angulate & Leaching Solution of Slag & $100 \%$ & [22] \\
\hline Amphidinium carterae & Leaching Solution of Slag & $100 \%$ & [22] \\
\hline Dunaliella tertiolecta & Slag or Leaching Solution of Slag & Arbitrary & [22] \\
\hline Tetraselmis tetrathele & Slag or Leaching Solution of Slag & Arbitrary & [22] \\
\hline Synechococcus sp. & Slag or Leaching Solution of Slag & Arbitrary & [22] \\
\hline Desmodesmus subspicatus & Slag or Leaching Solution of Slag & Arbitrary & [26] \\
\hline Chlorella vulgaris & Slag or Leaching Solution of Slag & Arbitrary & [26] \\
\hline Alexandrium tamarense & Slag or Leaching Solution of Slag & Arbitrary & [25] \\
\hline Nitzschia laevis & Slag or Leaching Solution of Slag & Arbitrary & [27] \\
\hline
\end{tabular}

This research selects converter slag and electric arc furnace slag as representatives, which are commonly used in the process of steelmaking, and aims to study effects and mechanisms of converter slag and EAF slag leaching solutions on the accumulation of chlorophyll a of Nannochloropsis sp. In order to compare the effects of accumulation of chlorophyll a under different adding proportions of converter slag and EAF slag leaching solutions and to explore the mechanisms of effects of steel slag leaching solution on the accumulation of chlorophyll a, different proportions of converter slag and EAF slag leaching solutions were added into F/ 2 medium to continuously culture Nannochloropsis sp. Through various characterization means, the main components of steel slag leaching solution, the effects of accumulation of chlorophyll a of Nannochloropsis sp., and the mechanisms and effects of steel slag leaching solution on the accumulation of chlorophyll a were analyzed and explained.

\section{Materials and Methods}

\subsection{Materials}

Table 2 lists the chemical compositions of converter slag and EAF slag used for this study. Converter slag (dried at $105^{\circ} \mathrm{C}$ for $12 \mathrm{~h}$, particle size 106-212 $\mu \mathrm{m}$ ) from one steel plant in Tangshan (Hebei, China) was used, and the chemical composition included calcium oxide $(46.60 \mathrm{wt} \%)$, ferric oxide $(31.52 \mathrm{wt} \%)$, silicon dioxide $(8.25 \mathrm{wt} \%)$, phosphorus pentoxide $(2.29 \mathrm{wt} \%)$, manganese oxide $(1.47 \mathrm{wt} \%)$, magnesium oxide $(4.10 \mathrm{wt} \%)$, alumina $(1.34 \mathrm{wt} \%)$, chromium trioxide (0.94 $\mathrm{wt} \%)$, vanadium pentoxide $(1.75 \mathrm{wt} \%)$, and titanium dioxide $(0.51 \mathrm{wt} \%)$. EAF slag (dried at $105^{\circ} \mathrm{C}$ for $12 \mathrm{~h}$, particle size $106-212 \mu \mathrm{m}$ ) from one steel plant in Lishui (Zhejiang, China) was used, and its chemical composition included calcium oxide ( $27.89 \mathrm{wt} \%)$, ferric oxide $(2.09 \mathrm{wt} \%)$, silicon dioxide (34.57 $\mathrm{wt} \%)$, phosphorus pentoxide $(0.01 \mathrm{wt} \%)$, manganese oxide $(5.96 \mathrm{wt} \%)$, magnesium oxide $(4.81 \mathrm{wt} \%)$, alumina $(3.81 \mathrm{wt} \%)$, chromium trioxide $(16.95 \mathrm{wt} \%)$, vanadium pentoxide $(0.26 \mathrm{wt} \%)$, and titanium dioxide (2.59 wt\%). Nannochloropsis sp. (GY-H14 Nannochloropsis sp. bacterial strain) from Guangyu Biological Technology Co., Ltd. (Shanghai, China) was used. Table 3 lists the chemical reagents used for this study. Chemical reagents cupric sulfate $(\geq 99 \%)$, sodium nitrate ( $\geq 99 \%)$, calcium hydroxide $(\geq 95 \%)$, sodium fluoride $(\geq 98 \%)$, potassium bromide ( $\geq 99 \%)$, anhydrous sodium sulfate $(\geq 99 \%)$, anhydrous sodium carbonate $(\geq 99.8 \%)$, potassium phosphate dibasic $(\geq 99 \%)$, magnesium sulfate $(\geq 99 \%)$, ethylenediamine tetra acetic acid disodium salt $(\geq 99 \%)$, sodium hydroxide $(\geq 96 \%)$, and anhydrous calcium chloride ( $\geq 96 \%$ ) from SHENTAI Chemical Industry Co., Ltd. (Tianjin, China); magnesium chloride hexahydrate (99\%) and sodium bicarbonate (99\%) from Aladdin Biochemical Technology Co., Ltd. (Shanghai, China); iron chloride hexahydrate (99\%), manganese chloride tetrahydrate $(99 \%)$, cobalt nitrate hexahydrate $(99 \%)$, calcium chloride dihydrate $(\geq 99.9 \%)$, cobalt 
chloride hexahydrate (99\%), strontium chloride hexahydrate $(99.5 \%)$, sodium hydrogen phosphate dihydrate $(99 \%)$, sodium metasilicate nonahydrate $(99 \%)$, iron citrate $(99 \%)$, vitamin B1 (98\%), vitamin B12 (98\%), and D-Biotin (vitamin H) (>98\%) from Macklin Biochemical Technology Co., Ltd. (Shanghai, China); sodium chloride ( $\geq 99.5 \%)$, magnesium oxide $(\geq 98 \%)$, boric acid ( $\geq 99.5 \%)$, and ethanol absolute $(\geq 99.7 \%)$ from YONGDA Chemical Reagent Co., Ltd. (Tianjin, China); molybdenum trioxide ( $\geq 99.5 \%)$ from Guanfu Fine Chemical Research Institute (Tianjin, China); potassium chloride ( $\geq 99.5 \%)$ from Baishi Chemical Industry Co., Ltd. (Tianjin, China); zinc sulfate heptahydrate $(\geq 99.5 \%)$ from Kemiou Chemical Reagent Co., Ltd. (Tianjin, China); and hydrochloric acid (36-38\%) from Kaixin Chemical Co., Ltd. (Tianjin, China) were selected in this experiment.

Table 2. Chemical compositions of converter slag and EAF slag used for this study, (wt $\%)$.

\begin{tabular}{ccccccccccc}
\hline Types of Slag & $\mathbf{C a O}$ & $\mathbf{F e}_{\mathbf{2}} \mathbf{O}_{\mathbf{3}}$ & $\mathbf{S i O}_{\mathbf{2}}$ & $\mathbf{P}_{\mathbf{2}} \mathbf{O}_{\mathbf{5}}$ & $\mathbf{M n O}$ & $\mathbf{M g O}$ & $\mathbf{A l}_{\mathbf{2}} \mathbf{O}_{\mathbf{3}}$ & $\mathbf{C r}_{\mathbf{2}} \mathbf{O}_{\mathbf{3}}$ & $\mathbf{V}_{\mathbf{2}} \mathbf{O}_{\mathbf{5}}$ & $\mathbf{T i O}_{\mathbf{2}}$ \\
\hline Converter Slag & 46.60 & 31.52 & 8.25 & 2.29 & 1.47 & 4.10 & 1.34 & 0.94 & 1.75 & 0.51 \\
EAF Slag & 27.89 & 2.09 & 34.57 & 0.01 & 5.96 & 4.81 & 3.81 & 16.95 & 0.26 & 2.59 \\
\hline
\end{tabular}

Table 3. Chemical reagents used for this study.

\begin{tabular}{|c|c|c|c|}
\hline Reagents & Purity & Manufacturer & Location \\
\hline Cupric Sulfate & $\geq 99 \%$ & \multirow{12}{*}{ SHENTAI Chemical Industry Co., Ltd. } & \multirow{12}{*}{ Tianjin, China } \\
\hline Sodium Nitrate & $\geq 99 \%$ & & \\
\hline Calcium Hydroxide & $\geq 95 \%$ & & \\
\hline Sodium Fluoride & $\geq 98 \%$ & & \\
\hline Potassium Bromide & $\geq 99 \%$ & & \\
\hline Sodium Sulfate Anhydrous & $\geq 99 \%$ & & \\
\hline Sodium Carbonate Anhydrous & $\geq 99.8 \%$ & & \\
\hline Potassium Phosphate Dibasic & $\geq 99 \%$ & & \\
\hline Magnesium Sulfate & $\geq 99 \%$ & & \\
\hline Ethylenediamine Tetraacetic Acid Disodium Salt & $\geq 99 \%$ & & \\
\hline Sodium Hydroxide & $\geq 96 \%$ & & \\
\hline Calcium Chloride Anhydrous & $\geq 96 \%$ & & \\
\hline Magnesium Chloride Hexahydrate & $99 \%$ & \multirow{2}{*}{$\begin{array}{l}\text { Aladdin Biochemical Technology } \\
\text { Co., Ltd. }\end{array}$} & \multirow{2}{*}{ Shanghai, China } \\
\hline Sodium Bicarbonate & $99 \%$ & & \\
\hline Iron Chloride Hexahydrate & $99 \%$ & \multirow{12}{*}{$\begin{array}{l}\text { Macklin Biochemical Technology } \\
\text { Co., Ltd. }\end{array}$} & \multirow{12}{*}{ Shanghai, China } \\
\hline Manganese Chloride Tetrahydrate & $99 \%$ & & \\
\hline Cobalt Nitrate Hexahydrate & $99 \%$ & & \\
\hline Calcium Chloride Dihydrate & $\geq 99.9 \%$ & & \\
\hline Cobalt Chloride Hexahydrate & $99 \%$ & & \\
\hline Strontium Chloride Hexahydrate & $99.5 \%$ & & \\
\hline Sodium Hydrogen Phosphate Dihydrate & $99 \%$ & & \\
\hline Sodium Metasilicate Nonahydrate & $99 \%$ & & \\
\hline Iron Citrate & $99 \%$ & & \\
\hline Vitamin B1 & $98 \%$ & & \\
\hline Vitamin B12 & $98 \%$ & & \\
\hline D-Biotin (Vitamin H) & $>98 \%$ & & \\
\hline Sodium Chloride & $\geq 99.5 \%$ & \multirow{4}{*}{ YONGDA Chemical Reagent Co., Ltd. } & \multirow{4}{*}{ Tianjin, China } \\
\hline Magnesium Oxide & $\geq 98 \%$ & & \\
\hline Boric Acid & $\geq 99.5 \%$ & & \\
\hline Ethanol Absolute & $\geq 99.7 \%$ & & \\
\hline Molybdenum Trioxide & $\geq 99.5 \%$ & $\begin{array}{l}\text { Guanfu Fine Chemical } \\
\text { Research Institute }\end{array}$ & Tianjin, China \\
\hline Potassium Chloride & $\geq 99.5 \%$ & Baishi Chemical Industry Co., Ltd. & Tianjin, China \\
\hline Zinc Sulfate Heptahydrate & $\geq 99.5 \%$ & Kemiou Chemical Reagent Co., Ltd. & Tianjin, China \\
\hline Hydrochloric Acid & $36-38 \%$ & Kaixin Chemical Co., Ltd. & Tianjin, China \\
\hline
\end{tabular}




\subsection{Preparation of Steel Slag Leaching Solution}

One liter of ultrapure water was added into a one-liter conical flask (ultrapure water machine, Exceed-Ad-32, Aike Environmental Protection Equipment Co., Ltd., Chengdu, China). Next, $50 \mathrm{mg}$ converter slag and $400 \mathrm{mg}$ EAF slag were soaked in ultrapure water to form $50 \mathrm{mg} / \mathrm{L}$ converter slag solution and $400 \mathrm{mg} / \mathrm{L}$ EAF slag solution, respectively. The $\mathrm{pH}$ value of the converter slag solution and the EAF slag solution was adjusted to 6 using hydrochloric acid. Slag was continuously oscillated in the solution of adjusted $\mathrm{pH}$ value (air bath thermostat, THZ-82A, Jinyi Instrument Technology Co., Ltd., Changzhou, China) and was soaked for $48 \mathrm{~h}$. Solution that was soaked for $48 \mathrm{~h}$ was filtered by filter water $(0.45 \mu \mathrm{m}$ aperture) to remove slag particles. Filtered converter slag and EAF slag leaching solutions were used in follow-up experiments.

\subsection{Artificial Seawater and F/2 Medium}

2.3.1. Artificial Seawater

Table 4 lists the compositions of artificial seawater used for this study. The artificial seawater has the following compositions (g/1 L ultrapure water): $21.1939 \mathrm{NaCl} ; 3.55 \mathrm{NaSO}_{4}$; $0.5993 \mathrm{KCl} ; 0.2935 \mathrm{NaHCO}_{3} ; 0.08627 \mathrm{KBr} ; 0.02297 \mathrm{H}_{3} \mathrm{BO}_{3} ; 0.00275 \mathrm{NaF} ; 9.5922 \mathrm{MgCl}_{2} \cdot 6 \mathrm{H}_{2} \mathrm{O}$; $1.0143 \mathrm{CaCl}_{2} ; 0.02186 \mathrm{SrCl}_{2} \cdot 6 \mathrm{H}_{2} \mathrm{O}$.

Table 4. Compositions of artificial seawater used for this study, (g/1 L ultrapure water).

\begin{tabular}{ccccccccccc}
\hline Compositions & $\mathbf{N a C l}$ & $\mathrm{NaSO}_{4}$ & $\mathrm{KCl}$ & $\mathbf{N a H C O}_{3}$ & $\mathbf{K B r}$ & $\mathbf{H}_{3} \mathbf{B O}_{3}$ & $\mathbf{N a F}$ & $\mathbf{M g C l}_{2} \cdot \mathbf{6} \mathbf{H}_{2} \mathbf{O}$ & $\mathbf{C a C l}_{2}$ & $\mathbf{S r C l}_{2} \cdot \mathbf{6} \mathbf{H}_{2} \mathbf{O}$ \\
\hline Content & 21.1939 & 3.55 & 0.5993 & 0.2935 & 0.08627 & 0.02297 & 0.00275 & 9.5922 & 1.0143 & 0.02186 \\
\hline
\end{tabular}

\subsubsection{F/2 Medium}

Table 5 lists compositions of $\mathrm{F} / 2$ medium used for this study. The $\mathrm{F} / 2$ medium has the following compositions (mg/1 L artificial seawater): $75 \mathrm{NaNO}_{3} ; 5.62 \mathrm{NaH}_{2} \mathrm{PO}_{4} \cdot 2 \mathrm{H}_{2} \mathrm{O}$; $30 \mathrm{Na}_{2} \mathrm{SiO}_{3} \cdot 9 \mathrm{H}_{2} \mathrm{O} ; 4.36 \mathrm{Na}_{2}-\mathrm{EDTA} ; 3.15 \mathrm{FeCl}_{3} \cdot 6 \mathrm{H}_{2} \mathrm{O} ; 0.0098 \mathrm{CuSO}_{4} \cdot 5 \mathrm{H}_{2} \mathrm{O} ; 0.022 \mathrm{ZnSO}_{4} \cdot 7 \mathrm{H}_{2} \mathrm{O}$; $0.01 \mathrm{CoCl}_{2} \cdot 6 \mathrm{H}_{2} \mathrm{O} ; 0.018 \mathrm{MnCl}_{2} \cdot 4 \mathrm{H}_{2} \mathrm{O} ; 0.1$ Vitamin B1; 0.0005 Vitamin B12; 0.0005 Vitamin $\mathrm{H}$.

Table 5. Compositions of F/2 medium used for this study, (mg/1 L artificial seawater).

\begin{tabular}{|c|c|c|c|c|c|c|c|c|c|c|c|c|}
\hline Cor & $\mathrm{NaNO}_{3}$ & $\begin{array}{c}\mathrm{NaH}_{2} \mathrm{PO}_{4} \\
2 \mathrm{H}_{2} \mathrm{O}\end{array}$ & $\begin{array}{c}\mathrm{Na}_{2} \mathrm{SiO}_{3} . \\
9 \mathrm{H}_{2} \mathrm{O}\end{array}$ & $\begin{array}{l}\mathrm{Na}_{2-} \\
\text { EDTA }\end{array}$ & $\begin{array}{l}\mathrm{FeCl}_{3} . \\
6 \mathrm{H}_{2} \mathrm{O}\end{array}$ & $\begin{array}{c}\mathrm{CuSO}_{4} \cdot \\
5 \mathrm{H}_{2} \mathrm{O}\end{array}$ & $\begin{array}{c}\mathrm{ZnSO}_{4} \cdot \\
7 \mathrm{H}_{2} \mathrm{O}\end{array}$ & $\begin{array}{c}\mathrm{CoCl}_{2} \cdot \\
6 \mathrm{H}_{2} \mathrm{O}\end{array}$ & $\begin{array}{c}\mathrm{MnCl}_{2} \cdot \\
4 \mathrm{H}_{2} \mathrm{O}\end{array}$ & $\begin{array}{c}\text { Vitamin } \\
\text { B1 }\end{array}$ & $\begin{array}{c}\text { Vitamin } \\
\text { B12 }\end{array}$ & $\underset{\mathbf{H}}{\text { Vitamin }}$ \\
\hline Content & 75 & 5.62 & 30 & 4.36 & 3.15 & 0.0098 & 0.022 & 0.01 & 0.018 & 0.1 & 0.0005 & 0.0005 \\
\hline
\end{tabular}

\subsection{Culturing of Nannochloropsis sp.}

On a pro rata of 10,30, 50, and $70 \mathrm{vol} \%$, converter slag and EAF slag leaching solutions were mixed with F/ 2 medium into $1 \mathrm{~L}$. Then, $5 \mathrm{vol} \%$ of Nannochloropsis sp. was added and continuously cultured for 15 days in light incubator (GXZ-500, Ningbo Jiangnan Instrument Factory, Ningbo, China) under culture conditions of LD circulation (12 h light $/ 12 \mathrm{~h}$ darkness), illumination intensity of $4000 \mathrm{lux}$ and temperature of $23^{\circ} \mathrm{C}$. In this experiment, F/2 medium without adding leaching solution of slag was designated as the control group. All the experiments in this research were carried out under constant light conditions, and the experimental devices are represented in Figure 1 below. 


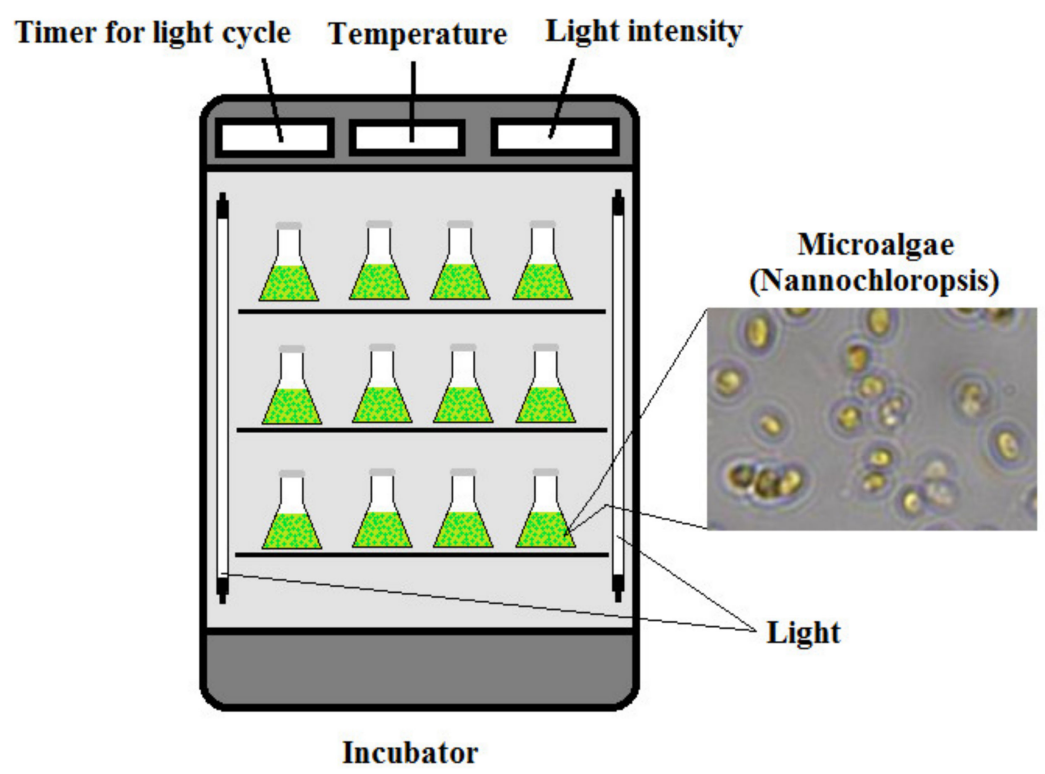

Figure 1. Experimental system used to culture microalgae in this study.

\subsection{Measurement of Chlorophyll A Concentration}

Twenty milliliters of liquid was taken from each sample that cultured Nannochloropsis sp. and a filter membrane $(0.45 \mu \mathrm{m})$ was used to filter it. After filtration, the filter membrane was taken out and put into a $50 \mathrm{~mL}$ liquid storage bottle after being cut into pieces. Next, $3600 \mu \mathrm{L}$ of $95 \%$ ethanol was added to the liquid storage bottle and then $400 \mu \mathrm{L}$ of distilled water was added. After being mixed evenly, it was heated in an oil bath (constant temperature heating magnetic stirrer, DF-101S, LICHEN-Bx Instrument Technology Co., Ltd., Shanghai, China) for $15 \mathrm{~min}$ at $75^{\circ} \mathrm{C}$ and cooled naturally to room temperature. When there was no obvious green on the filter membrane, chlorophyll a was considered to have been extracted completely. A Disposable syringe and a $0.22 \mu \mathrm{m}$ filter membrane were used to transfer the filtrate from the liquid storage bottle to a cuvette. An ultraviolet spectrophotometer (U-T3, Yipu Instrument Manufacturing Co., Ltd., Shanghai, China) was used to measure and record the absorbance under wavelengths of 649,665 , and $750 \mathrm{~nm}$. According to Formula (1), concentration of chlorophyll a was calculated.

$$
\text { Chlorophyll a }(\mathrm{mg} / \mathrm{L})=5.24 \times\left(\mathrm{A}_{665}-\mathrm{A}_{750}\right)+22.4 \times\left(\mathrm{A}_{649}-\mathrm{A}_{750}\right)
$$

\subsection{Characterization of Steel Slag and Steel Slag Leaching Solution}

Chemical compositions and content of converter slag and EAF slag used in this experiment were characterized by X-ray fluorescence spectrum (XRF, ZSX Primus II 03030429, Rigaku Corporation, Tokyo, Japan).

The contents of main elements in converter slag and EAF slag leaching solutions and the contents of $\mathrm{Ca}^{2+}$ and $\mathrm{Mg}^{2+}$ in $\mathrm{F} / 2$ medium containing steel slag leaching solution before and after culturing Nannochloropsis sp. were characterized by inductively coupled plasma mass spectrometry (ICP-MS, 7800 type inductively coupled plasma mass spectrometry, Agilent Technologies Inc., Santa Clara, CA, USA).

The $\mathrm{pH}$ values of the $\mathrm{F} / 2$ medium, converter slag, and EAF slag leaching solutions were characterized by a $\mathrm{pH}$ meter (PHS-3C, Yueping Scientific Instrument Co., Ltd., Shanghai, China).

Contents of $\mathrm{CO}_{2}$ (aq) of the $\mathrm{F} / 2$ medium, converter slag, and EAF slag leaching solutions were characterized by a carbon dioxide concentration meter ( $\mathrm{PXS}-\mathrm{CO}_{2}$ type, Feng Pro Electronic Technology Co., Ltd., Shanghai, China). 


\subsection{Effects of Components in Steel Slag Leaching Solution on Concentration of $\mathrm{CO}_{2}$ (aq)}

$\mathrm{CO}_{2}$ (aq) and $\mathrm{HCO}_{3}{ }^{-}$in aqueous solution exist in the form of carbonate, as shown in Formulas (2)-(4):

$$
\begin{gathered}
\mathrm{CO}_{2} \text { (gas) } \leftrightarrow \mathrm{CO}_{2}(\mathrm{aq}) \\
\mathrm{H}_{2} \mathrm{O}+\mathrm{CO}_{2}(\mathrm{aq}) \leftrightarrow \mathrm{H}_{2} \mathrm{CO}_{3}(\mathrm{aq}) \leftrightarrow \mathrm{HCO}_{3}{ }^{-}+\mathrm{H}^{+} \\
\mathrm{HCO}_{3}{ }^{-} \leftrightarrow \mathrm{CO}_{3}{ }^{2-}+\mathrm{H}^{+}
\end{gathered}
$$

In the above-mentioned forms of carbonate, $\mathrm{CO}_{2}(\mathrm{aq})$ is necessary for aquatic photosynthetic organisms, including phytoplankton. After quantitative measurement of chemical elements in the steel slag leaching solution, the concentration of $\mathrm{CO}_{2}(\mathrm{aq})$ was also tested. This experiment did not include algae to remove the effects from algae on the concentration of $\mathrm{CO}_{2}(\mathrm{aq})$ in the data.

In this research, under acid condition $(\mathrm{pH} \leq 4.0), \mathrm{HCO}_{3}{ }^{-}$and $\mathrm{CO}_{3}{ }^{2-}$ could be estimated as $\mathrm{CO}_{2}$ (aq). By adding a solution of adjustable $\mathrm{pH}$ value $(333 \mathrm{mM}$ citrate and $1.41 \mathrm{M}$ sodium chloride) ( $\mathrm{pH}$ 1.3), all the forms of carbonate, except $\mathrm{CO}_{2}$ (aq) were transformed into $\mathrm{CO}_{2}$ (aq). Then, estimation was finished by using the total amount of carbonate. The concentrations of $\mathrm{CO}_{2}(\mathrm{aq}), \mathrm{HCO}_{3}{ }^{-}$and $\mathrm{CO}_{3}{ }^{2-}$ were calculated from the total amount of carbonate and $\mathrm{pH}$ value according to Henderson-Hasselbalch Formulas (5) and (6):

$$
\begin{aligned}
& p H=p K_{1}+\log \left(\frac{\left[\mathrm{HCO}_{3}^{-}\right]}{\left[\mathrm{CO}_{2}(a q)\right]}\right) \\
& p H=p K_{2}+\log \left(\frac{\left[\mathrm{CO}_{3}^{2-}\right]}{\left[\mathrm{HCO}_{3}^{-}\right]}\right)
\end{aligned}
$$

Since it was difficult to distinguish $\mathrm{CO}_{2}(\mathrm{aq})$ from $\mathrm{H}_{2} \mathrm{CO}_{3}(\mathrm{aq})$ in solution, $\left[\mathrm{H}_{2} \mathrm{CO}_{3}\right.$ (aq)] in Formula (3) was expressed as $\mathrm{CO}_{2}$ (aq) in Formula (5). In the formula, $\mathrm{pK}_{1}=6.35$, $\mathrm{pK}_{2}=10.33$.

\subsection{Effects of Concentrations of $\mathrm{Ca}^{2+}$ and $\mathrm{Mg}^{2+}$ on Concentration of $\mathrm{CO}_{2}$ (aq)}

Briefly, 50, 100, 200, and $400 \mathrm{mg}$ calcium and magnesium oxide were added into $1 \mathrm{~L}$ $\mathrm{F} / 2$ medium. Concentration of $\mathrm{CO}_{2}(\mathrm{aq})$ under conditions of different concentrations of $\mathrm{Ca}^{2+}$ and $\mathrm{Mg}^{2+}$ was test by carbon dioxide concentration meter (PXS- $\mathrm{CO}_{2}$ type, Feng Pro Electronic Technology Co., Ltd., Shanghai, China).

\section{Results and Discussion}

\subsection{Main Components of Steel Slag Leaching Solution}

Since it is difficult to distinguish Fe compounds from $\mathrm{Cr}$ compounds in suspended metal solution after alkaline-fusion, the $\mathrm{Fe}$ compound and $\mathrm{Cr}$ compound in converter slag and EAF slag used in this experiment were called $\mathrm{Fe}_{2} \mathrm{O}_{3}$ or $\mathrm{Cr}_{2} \mathrm{O}_{3}$. According to the data in Table 2, the converter slag used in this experiment contained $\mathrm{CaO}, \mathrm{Fe}_{2} \mathrm{O}_{3}, \mathrm{P}_{2} \mathrm{O}_{5}$, and $\mathrm{V}_{2} \mathrm{O}_{5}$, higher than that in EAF slag. In particular, for $\mathrm{CaO}, \mathrm{Fe}_{2} \mathrm{O}_{3}$, and $\mathrm{P}_{2} \mathrm{O}_{5}$, the existing quantity in converter slag was much higher than that in EAF slag. Contents of $\mathrm{SiO}, \mathrm{MnO}$, $\mathrm{Al}_{2} \mathrm{O}_{3}, \mathrm{Cr}_{2} \mathrm{O}_{3}$, and $\mathrm{TiO}_{2}$ in converter slag were lower than that in EAF slag. Especially for $\mathrm{SiO}_{2}$ and $\mathrm{Cr}_{2} \mathrm{O}_{3}$, the existing quantity in converter slag was much lower than that in EAF slag. The presence of $\mathrm{MgO}$ in converter slag was not significantly different from that in EAF slag.

Table 6 lists the concentrations of main elements in converter slag and EAF slag leaching solutions. Concentration of Total Ca in converter slag and EAF slag leaching solutions were relatively high (5.63 and $2.22 \mathrm{mg} / \mathrm{L}$, respectively), the reason of which was that in these two kinds of leaching solutions, the content of $\mathrm{CaO}$ was relatively high, reaching to 46.60 and $27.89 \mathrm{wt} \%$, respectively. Content of $\mathrm{Fe}_{2} \mathrm{O}_{3}$ in converter slag was also relatively high $(31.52 \mathrm{wt} \%)$. However, in converter slag leaching solution, the concentration 
of Total Fe was very low, only $0.8 \times 10^{-3} \mathrm{mg} / \mathrm{L}$, the reason for which was the different solubility of different elements in water.

Table 6. Concentrations of main elements in converter slag and EAF slag leaching solutions, (mg/L).

\begin{tabular}{|c|c|c|c|c|}
\hline Main Elements in Slag & $\begin{array}{c}\text { Converter Slag } \\
\text { Leaching Solution }\end{array}$ & $\begin{array}{l}\text { EAF Slag Leaching } \\
\text { Solution }\end{array}$ & $\begin{array}{c}\text { Waste Synthetical } \\
\text { Discharge Standard a }\end{array}$ & $\begin{array}{l}\text { Standard of Drinking } \\
\text { Water for Life }\end{array}$ \\
\hline Total $\mathrm{Mg}$ & $5.1 \times 10^{-2}$ & $1.8 \times 10^{-1}$ & & $4.5 \times 10^{2}$ \\
\hline Total Al & $1.2 \times 10^{-2}$ & $3.1 \times 10^{-2}$ & & 0.2 \\
\hline Total Ca & 5.6 & 2.2 & & $4.5 \times 10^{2}$ \\
\hline Total Fe & $0.8 \times 10^{-3}$ & $0.4 \times 10^{-3}$ & & 0.3 \\
\hline $\mathrm{Cr}(\mathrm{VI})$ & $0.1 \times 10^{-4}$ & $0.7 \times 10^{-4}$ & 0.5 & $0.5 \times 10^{-1}$ \\
\hline Total Mn & $0.1 \times 10^{-2}$ & $3.9 \times 10^{-2}$ & 0.1 & 0.1 \\
\hline Total V & $6.8 \times 10^{-2}$ & $0.1 \times 10^{-3}$ & & \\
\hline Total P & $5.1 \times 10^{-2}$ & $0.8 \times 10^{-3}$ & 0.5 & \\
\hline
\end{tabular}

${ }^{\mathrm{a}}$ Reference Standard: GB 8978-1996. ${ }^{\mathrm{b}}$ Reference Standard: GB 5749-2006.

In order to discuss the influence of converter slag and EAF slag leaching solutions on the water environment, the concentrations of main elements in converter slag and EAF slag leaching solutions were compared with the emission standard of the national integrated wastewater discharge standard (GB 8978-1996) and the national sanitary standard of drinking water for life (GB 5749-2006). After comparing the concentration of main elements in the leaching solutions of converter slag and electric arc furnace slag in Table 6 with the national integrated wastewater discharge standard (GB 8978-1996) and the national sanitary standard of drinking water for life (GB 5749-2006), it was found that concentrations of main elements in these two leaching solutions were lower than the two standards.

In this research, a steel slag leaching experiment was carried out using $\mathrm{pH}$ adjusted ultrapure water, which differs from the natural water in that it contains a variety of substances.

The experimental design might be too simple to elucidate the leaching phenomenon of steel slag in a natural aquatic environment. To prevent steel slag from polluting the natural aquatic environment, additional leaching experiments with natural water are required.

\subsection{Effects of Steel Slag Leaching Solution on Accumulation of Chlorophyll A}

The content of chlorophyll a, one of the indexes reflexing growth of microalgae, is usually used to measure the growth of microalgae. The increase of chlorophyll a fluorescence value in vivo in microalgae means that growth of microalgae is promoted, while the decrease means it is inhibited [28]. The chlorophyll a method is usually used to measure the biomass of microalgae. There is a significant positive correlation between chlorophyll a and biomass [29]. Thus, biomass increases with the increase of content of chlorophyll a.

Figure 2 shows the relations between concentration of chlorophyll a of Nannochloropsis $\mathrm{sp}$. and addition of converter slag leaching solution. Results show that when the addition of converter slag leaching solution was less than $50 \mathrm{vol} \%$, concentrations of chlorophyll a added to converter slag leaching solution were higher than that of control group. Concentration of chlorophyll a decreased with the increase of addition of converter slag leaching solution. Thus, when addition of converter slag leaching solution was less than $50 \mathrm{vol} \%$, accumulation of chlorophyll a of Nannochloropsis sp. could be promoted. The promoting effect decreased with the increase of addition of converter slag leaching solution. When the addition of converter slag leaching solution was $10 \mathrm{vol} \%$, the concentration of chlorophyll a reached the highest $(4.2 \mathrm{mg} / \mathrm{L}), 1.45$ times as much as that of control group, so when addition of converter slag leaching solution was $10 \mathrm{vol} \%$, the promoting effect was the best. When the addition of converter slag leaching solution was $70 \mathrm{vol} \%$, the concentration of chlorophyll a was lower than that of the control group, so under this addition, accumulation of chlorophyll a of Nannochloropsis sp. was inhibited. 


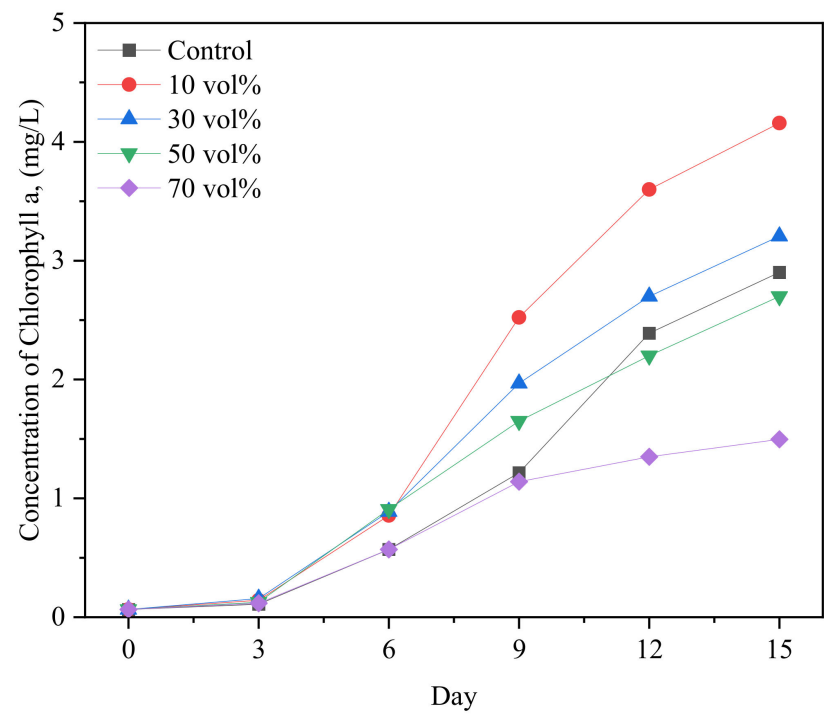

Figure 2. Effects of various additions (vol\%) of converter slag leaching solution on concentration of chlorophyll a (mg/L).

Figure 3 shows the relations between the concentration of chlorophyll a of Nannochloropsis sp. and the addition of EAF slag leaching solution. Results show that when the addition of EAF slag leaching solution was less than $50 \mathrm{vol} \%$, concentrations of chlorophyll a added to EAF slag leaching solution were higher than that of control group. The concentration of chlorophyll a decreased with the increase of amount of EAF slag leaching solution added. Thus, when the addition of EAF slag leaching solution was less than $50 \mathrm{vol} \%$, accumulation of chlorophyll a of Nannochloropsis sp. was promoted. The promoting effect decreased with the increase of addition of EAF slag leaching solution. When addition of EAF slag leaching solution was $10 \mathrm{vol} \%$, the concentration of chlorophyll a reached its highest level $(3.2 \mathrm{mg} / \mathrm{L}), 1.10$ times as much as that of control group, so when addition amount of EAF slag leaching solution was $10 \mathrm{vol} \%$, the promoting effect was the best. When the addition amount of EAF slag leaching solution was $70 \mathrm{vol} \%$, the concentration of chlorophyll a was lower than that of control group, so when the addition amount of EAF slag leaching solution was $70 \mathrm{vol} \%$, the accumulation of chlorophyll a of Nannochloropsis sp. was inhibited.

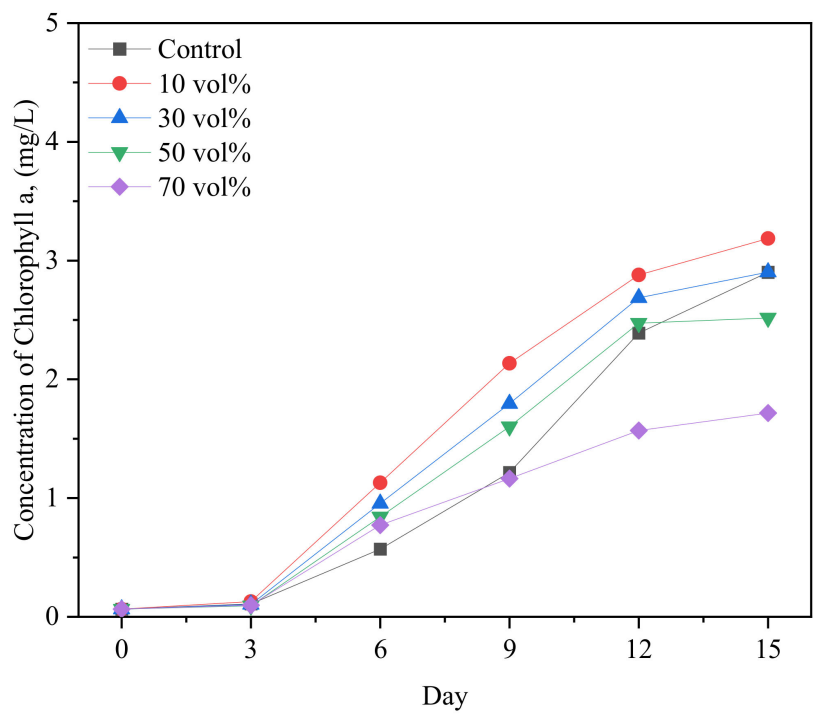

Figure 3. Effects of various additions ( $\mathrm{vol} \%$ ) of EAF slag leaching solution on concentration of chlorophyll a (mg/L). 
After comprehensively comparing the relationship between the concentration of chlorophyll a of Nannochloropsis sp. and the addition of converter slag and EAF slag leaching solutions, it was found that effects of converter slag and EAF slag leaching solutions on accumulation of chlorophyll a of Nannochloropsis sp. showed the same trend. When the addition of these two kinds of leaching solutions was less than $50 \mathrm{vol} \%$, the accumulation of chlorophyll a of Nannochloropsis sp. was promoted, while when it was $10 \mathrm{vol} \%$, the accumulation reached the highest. When the addition of these two kinds of leaching solution was $70 \mathrm{vol} \%$, the accumulation of chlorophyll a of Nannochloropsis sp. was inhibited. Under the same addition proportion, the promoting or inhibiting effect on accumulation of chlorophyll a of Nannochloropsis sp. from converter slag leaching solution was more obvious than that for EAF slag leaching solution.

\subsection{Effects of Elements in Steel Slag Leaching Solution on Concentration of $\mathrm{CO}_{2}$ (aq)}

Until now, it is still unclear why the accumulation of chlorophyll a in the medium containing steel slag leaching solution is higher than in that without steel slag leaching solution. To a great extent, accumulation of chlorophyll a of terrestrial plant, microalgae, and other photosynthetic organisms relies on photosynthetic efficiency. Photosynthesis can be mainly divided into two metabolic systems, that is, light-dependent reaction (attaining light energy from sunshine) and Calvin cycle (immobilizing $\mathrm{CO}_{2}$ to synthesize glucose). An increase of $\mathrm{CO}_{2}$ (aq) concentration can increase the photosynthetic rate, inhibit the respiration rate, promote the accumulation of chlorophyll a, and increase biomass [30]. The increase of $\mathrm{CO}_{2}(\mathrm{aq})$ promoted microalgae to absorb $\mathrm{CO}_{2}$ through photosynthesis [31]; however, the concentration of $\mathrm{CO}_{2}$ (gas) in air determined the concentration of $\mathrm{CO}_{2}$ (aq) soluble in water. Thus, the concentration of $\mathrm{CO}_{2}$ (gas) was the key factor driving the rate of photosynthesis [32] not only for terrestrial plants using $\mathrm{CO}_{2}$ (gas) directly but also for aquatic plankton using dissolved $\mathrm{CO}_{2}(\mathrm{aq})$ in water. This research studies the concentration of $\mathrm{CO}_{2}$ in relation to the Calvin cycle.

The mixture configured by $\mathrm{NaHCO}_{3}$ and $\mathrm{HCl}$ was used as reference standard of $\mathrm{CO}_{2}$ (aq). Emergence of $\mathrm{CO}_{2}$ (aq) depended on the concentration ratio of these two materials. According to Formula (7), the calculation was performed.

$$
\mathrm{NaHCO}_{3}+\mathrm{HCl} \rightarrow \mathrm{NaCl}+\mathrm{CO}_{2}(\mathrm{aq})+\mathrm{H}_{2} \mathrm{O}
$$

$\mathrm{CO}_{2}$ (aq) was measured by a PXS- $\mathrm{CO}_{2}$ type carbon dioxide concentration meter, and the concentration of $\mathrm{CO}_{2}(\mathrm{aq})$ under all the experimental conditions was tested (Figure 4). The $\mathrm{pH}$ value of the medium containing steel slag leaching solution was the same as that of the control group $(\mathrm{pH}=7.3)$. According to the Henderson-Hasselbalch equation, under $10 \mathrm{vol} \%$ converter slag and EAF slag leaching solutions condition, the concentration of $\mathrm{CO}_{2}$ (aq) in the medium containing $10 \mathrm{vol} \%$ of converter slag leaching solution was $3.8 \mathrm{mg} / \mathrm{L}$, while it was $3.5 \mathrm{mg} / \mathrm{L}$ in the medium containing 10 vol\% of EAF slag leaching solution, both higher than that of the control group $(3.0 \mathrm{mg} / \mathrm{L})$.

Thus, adding steel slag leaching solution can improve the water environment of microalgae. Compared with the experiment that only used F/2 medium, photosynthesis of microalgae could be further promoted. Additionally, compared with the control group, an increased concentration of $\mathrm{CO}_{2}$ (aq) by adding steel slag leaching solution could further promote the accumulation of chlorophyll a of Nannochloropsis sp. (Figures 2 and 3). Compared with EAF slag leaching solution, converter slag leaching solution could better promote the accumulation of chlorophyll a of Nannochloropsis sp., which could also be explained by the different concentrations of $\mathrm{CO}_{2}(\mathrm{aq})$ between converter slag and EAF slag leaching solutions. 


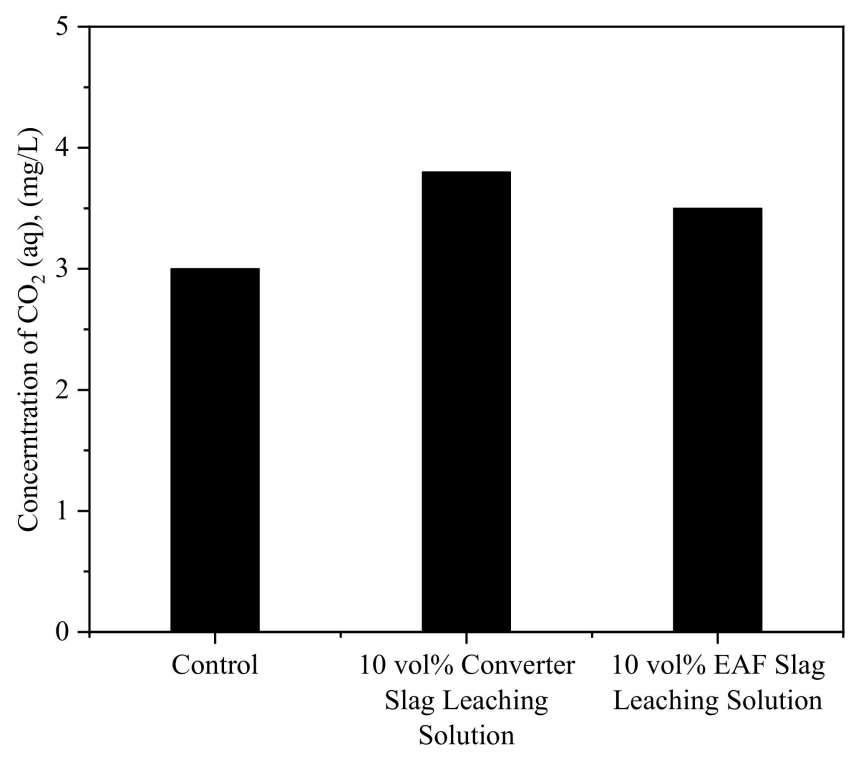

Figure 4. Concentrations of aqueous $\mathrm{CO}_{2}$ in control, $10 \mathrm{vol} \%$ converter slag leaching solution and $10 \mathrm{vol} \%$ EAF slag leaching solution.

\subsection{Relations between Concentrations of $\mathrm{Ca}^{2+}$ and $\mathrm{CO}_{2}$ (aq) in Steel Slag Leaching Solution}

The hardness of water is usually expressed by the contents of $\mathrm{Ca}^{2+}$ and $\mathrm{Mg}^{2+} . \mathrm{Ca}^{2+}$ and $\mathrm{Mg}^{2+}$ are alkaline-earth metals and easily react with carbonate. Meanwhile, contents of these elements in steel slag leaching solution are higher than that of other elements (Figure 2). Leaching process of $\mathrm{CaO}$ in slag can be assumed as the expressions in Formulas (8) and (9).

$$
\begin{aligned}
& \mathrm{CaO}(\text { solid })+\mathrm{H}_{2} \mathrm{O} \rightarrow \mathrm{Ca}(\mathrm{OH})_{2} \text { (solid) } \\
& \mathrm{Ca}(\mathrm{OH})_{2} \text { (solid) } \rightarrow \mathrm{Ca}^{2+}+2 \mathrm{OH}^{-}
\end{aligned}
$$

Although reactions of $\mathrm{MgO}$ and $\mathrm{CaO}$ could be assumed to be similar, the solubility of hydrated magnesium in water was much lower than that of hydrate calcium [33]. It was assumed that very low content of $\mathrm{MgO}$ (whose solubility in water is slightly higher than that of hydrated magnesium) could dissolve in water. Since all the experiments in this research were carried out under the condition of near neutral $\mathrm{pH}$, though $\mathrm{MgO}$ could react with acid, reactivity of $\mathrm{MgO}$ leaching from slag was not high. As a result, from the perspective of the nature of $\mathrm{MgO}, \mathrm{MgO}$ would not show high reactivity in the medium. Thus, this research studied the behavior of $\mathrm{Ca}^{2+}$ specifically. Figure 5 shows the relations between contents of different forms of carbonate calculated by the HendersonHasselbalch equation and $\mathrm{pH}$ value. In this research, under an experimental condition of $\mathrm{pH}=7.3$, among different the forms of carbonate, content of $\mathrm{HCO}_{3}{ }^{-}$was the highest. As a result, $\mathrm{Ca}^{2+}$ in leaching solution might react with $\mathrm{HCO}_{3}{ }^{-}$, as is shown in Formula (10). According to Formulas (2) and (3), bicarbonate compound might help the solution absorb $\mathrm{CO}_{2}$ from air.

$$
\mathrm{Ca}^{2+}+2 \mathrm{HCO}_{3}{ }^{-} \rightarrow \mathrm{Ca}\left(\mathrm{HCO}_{3}\right)_{2}(\mathrm{aq})
$$

$\mathrm{Ca}\left(\mathrm{HCO}_{3}\right)_{2}$ could completely ionize, thus in the form of $\mathrm{HCO}_{3}{ }^{-}, \mathrm{Ca}\left(\mathrm{HCO}_{3}\right)_{2}$ might disturb the chemical equilibrium among different forms of carbonate. The concentration ratio of different forms of carbonate in solution must be constant, an increase in the concentration of $\mathrm{HCO}_{3}{ }^{-}$makes Formula (3) proceed to the left, causing the increase of $\mathrm{CO}_{2}$ (aq), while the increased $\mathrm{CO}_{2}$ (aq) might be consumed by microalgae as raw materials for photosynthesis. 


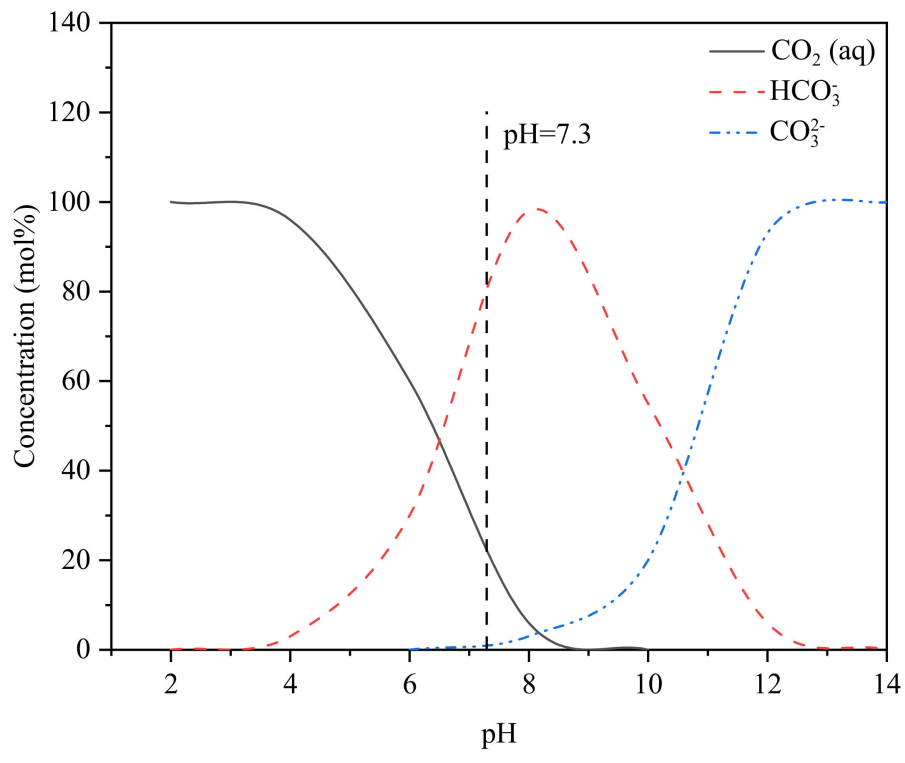

Figure 5. Concentrations of aqueous $\mathrm{CO}_{2}, \mathrm{HCO}_{3}{ }^{-}$, and $\mathrm{CO}_{3}{ }^{2-}$ for each $\mathrm{pH}(\mathrm{mol} \%)$.

In order to test the relations between contents of $\mathrm{Ca}^{2+}$ and $\mathrm{Mg}^{2+}$ in leaching solution of slag and concentration of $\mathrm{CO}_{2}(\mathrm{aq}), 50,100,200$, and $400 \mathrm{mg} / \mathrm{L} \mathrm{Ca}(\mathrm{OH})_{2}$ and $\mathrm{MgO}$ were added into F/2 medium, respectively. Then concentration of $\mathrm{CO}_{2}(\mathrm{aq})$ in compound was tested. As is shown in Figure 6, the concentration of $\mathrm{Ca}(\mathrm{OH})_{2}$ was related to the concentration of $\mathrm{CO}_{2}(\mathrm{aq})$. The concentration of $\mathrm{CO}_{2}(\mathrm{aq})$ increased with the increase in concentration of $\mathrm{Ca}(\mathrm{OH})_{2}$. However, since its solubility was relatively low, the concentration of $\mathrm{MgO}$ in the test concentration range showed no great effects on the concentration of $\mathrm{CO}_{2}(\mathrm{aq})$ in the compound.

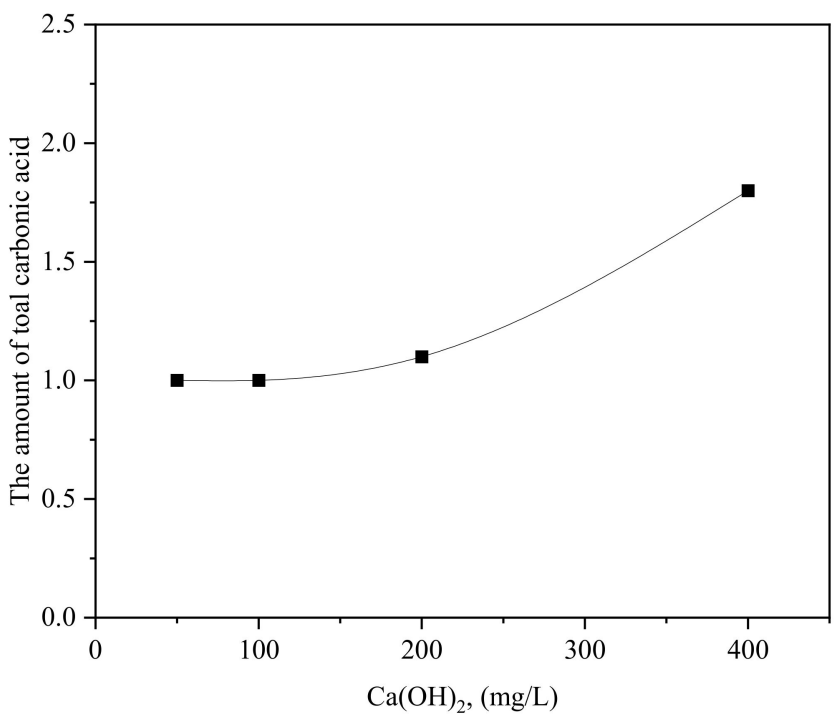

Figure 6. Relation between the amount of total carbonic acid and $\mathrm{Ca}(\mathrm{OH})_{2}$ content in solution.

With regard to effect of $\mathrm{Ca}^{2+}$ on concentration of $\mathrm{CO}_{2}(\mathrm{aq})$, a part of $\mathrm{Ca}^{2+}$ in solution might remain in the medium, so it could not be completely absorbed by Nannochloropsis sp. In order to test effect of $\mathrm{Ca}^{2+}$ on concentration of $\mathrm{CO}_{2}(\mathrm{aq})$, the concentrations of $\mathrm{Ca}^{2+}$ (Figure 2) in F/2 medium after the addition of converter slag and EAF slag leaching solutions before and after culturing Nannochloropsis sp. were tested, and concentrations of $\mathrm{Mg}^{2+}$ under the same condition were listed to be used for reference. 
In this research, it was found that $\mathrm{Ca}^{2+}$ was a factor for promoting the increase of concentration of $\mathrm{CO}_{2}(\mathrm{aq})$ in steel slag leaching solution. The experiment proved that adding $\mathrm{Ca}(\mathrm{OH})_{2}$ could increase the concentration of $\mathrm{CO}_{2}$ (aq) (Figure 6). In the $\mathrm{F} / 2$ medium with the addition of converter slag and EAF slag leaching solutions before and after culturing Nannochloropsis sp., enough amount of $\mathrm{Ca}^{2+}$ and $\mathrm{Mg}^{2+}$ existed to react with carbonate (Table 7). Apart from $\mathrm{Ca}(\mathrm{OH})_{2}$ and $\mathrm{MgO}$, some solutes in the steel slag leaching solution could also react in the F/2 medium to form complex ions and other molecular forms. These hypothetical molecular morphologies composed by second-group elements might be related with the increase of concentration of $\mathrm{CO}_{2}$ (aq). Further research needs to be carried out to explain the reason due to which the increase of steel slag leaching solution can increase the total content of carbonate and which kinds of molecular forms relate to the increase of concentration of $\mathrm{CO}_{2}(\mathrm{aq})$.

Table 7. Concentrations of $\mathrm{Ca}^{2+}$ and $\mathrm{Mg}^{2+}$ in $\mathrm{F} / 2$ medium containing steel slag leaching solution before and after culturing Nannochloropsis sp.

\begin{tabular}{ccccc}
\hline & \multicolumn{2}{c}{ Concentration of $\mathbf{C a}^{2+}(\mathbf{m g} / \mathbf{L})$} & \multicolumn{2}{c}{ Concentration of $\mathbf{M g}^{\mathbf{2 +}}(\mathbf{m g} / \mathbf{L})$} \\
\cline { 2 - 5 } & Before Culturing & After Culturing & Before Culturing & After Culturing \\
\hline Converter Slag Leaching Solution & 371.14 & 271.71 & 1134.56 & 483.10 \\
EAF Slag Leaching Solution & 367.73 & 254.11 & 1134.07 & 471.38 \\
\hline
\end{tabular}

\section{Conclusions}

This research carried out a leaching test of converter slag and EAF slag leaching solutions. Effects and mechanisms of steel slag leaching solution on Nannochloropsis sp. were explored. Conclusion of this research can be summed up in the following points.

(1) Adding converter slag and EAF slag leaching solutions into the F/2 medium influenced the accumulation of chlorophyll a of Nannochloropsis sp. When the addition of these two kinds of leaching solutions was less than $50 \mathrm{vol} \%$, the accumulation of chlorophyll a of Nannochloropsis sp. was promoted. While when addition was at $70 \mathrm{vol} \%$, it was inhibited. When the addition of converter slag leaching solution was $10 \mathrm{vol} \%$, accumulation of chlorophyll a reached the highest $(4.2 \mathrm{mg} / \mathrm{L}), 1.45$ times as much as that of control group. When $10 \mathrm{vol} \%$ of EAF slag leaching solution was added, accumulation of chlorophyll a was $3.2 \mathrm{mg} / \mathrm{L}, 1.10$ times as much as that of the control group. Under the same adding ratio, promoting and inhibitory effects of converter slag leaching solution on accumulation of chlorophyll a were higher than that of EAF slag leaching solution.

(2) The reason to the increase of chlorophyll a of Nannochloropsis sp. was that $\mathrm{Ca}^{2+}$ in converter slag and EAF slag leaching solutions increased the content of $\mathrm{CO}_{2}(\mathrm{aq})$, then the rate of photosynthesis and the growth rate of algae were improved.

Results of this research show that the use of slag not only promotes the growth of aquatic photosynthetic organisms in aquatic environment but it also promotes the absorption of $\mathrm{CO}_{2}$ through photosynthesis. Additionally, the increased $\mathrm{CO}_{2}(\mathrm{aq})$ makes secondary contributions to enhance yields of fish and shellfish, because the increased $\mathrm{CO}_{2}$ (aq) promotes the growth of both microalgae in aquatic ecosystem and that of fish and shellfish feeding on the phytoplankton.

Meanwhile, there are such elements as Fe, $\mathrm{P}, \mathrm{Ca}$, and $\mathrm{Mg}$ in the slag, which can be used as nutrients to promote the growth and reproduction of microalgae and to improve the accumulation of chlorophyll a and metabolites of microalgae. Thus, the use of slag is beneficial to decrease the cost of the culturing of microalgae.

Author Contributions: Conceptualization, Y.W.; writing-original draft preparation, T.L.; writingreview and editing, Q.Y., S.C., D.G., X.W., F.W., Y.W., J.L. and Y.Z.; funding acquisition, Y.W. and Y.Z. All authors have read and agreed to the published version of the manuscript. 
Funding: The authors wish to acknowledge the financial support from the National Natural Science Foundation of China (Nos.: 52004095 and 51704119) and the Natural Science Foundation of Hebei Province (E2017209243) and the Department of Education of Hebei Province (BJ2019038).

Institutional Review Board Statement: Not applicable.

Informed Consent Statement: Not applicable.

Data Availability Statement: Not applicable.

Acknowledgments: The authors give thanks to the anonymous reviewers and all the editors in the process of manuscript revision.

Conflicts of Interest: The authors declare no conflict of interest.

\section{References}

1. Tian, J.L.; Zhang, Q. Resource Utilization of Steel Slag and Environmental Pollution Treatment. Resour. Recycl. $2013,1,55-57$.

2. Dyudkin, D.A.; Grinberg, S.E. Continuous-Discrete Method of Making Steel. Metallurgist 2001, 45, 326-328. [CrossRef]

3. Proctor, D.M.; Fehling, K.A.; Shay, E.C.; Wittenborn, J.L.; Green, J.J.; Avent, C.; Bigham, R.D.; Connolly, M.; Lee, B.; Shepker, T.O.; et al. Physical and Chemical Characteristics of Blast Furnace, Basic Oxygen Furnace, and Electric Arc Furnace Steel Industry Slags. Environ. Sci. Technol. 2000, 34, 1576-1582. [CrossRef]

4. Huo, B.B.; Li, B.L.; Huang, S.Y.; Chen, C.; Zhang, Y.M.; Banthia, N. Hydration and soundness properties of phosphoric acid modified steel slag powder. Constr. Build. Mater. 2020, 254, 119319. [CrossRef]

5. Liao, Y.; Jiang, G.; Wang, K.; Al Qunaynah, S.; Yuan, W. Effect of steel slag on the hydration and strength development of calcium sulfoaluminate cement. Constr. Build. Mater. 2020, 265, 120301. [CrossRef]

6. Liu, J.; Yu, B.; Wang, Q. Application of steel slag in cement treated aggregate base course. J. Clean. Prod. 2020, $269,121733$. [CrossRef]

7. Wang, X.; Ni, W.; Li, J.; Zhang, S.; Hitch, M.; Pascual, R. Carbonation of steel slag and gypsum for building materials and associated reaction mechanisms. Cem. Concr. Res. 2019, 125, 105893. [CrossRef]

8. Galán-Arboledas, R.J.; Diego, J.Á.D.; Dondi, M.; Bueno, S. Energy, environmental and technical assessment for the incorporation of EAF stainless steel slag in ceramic building materials. J. Clean. Prod. 2016, 142, 1778-1788. [CrossRef]

9. Deng, L.; Jia, R.; Yun, F.; Zhang, X.; Li, H.; Zhang, M.; Jia, X.; Ren, D.; Li, B. Influence of $\mathrm{Cr}_{2} \mathrm{O}_{3}$ on the Viscosity and Crystallization Behavior of Glass Ceramics Based on Blast Furnace Slag. Mater. Chem. Phys. 2019, 240, 122212. [CrossRef]

10. Zhao, G.Z.; Li, Y.; Dai, W.B.; Cang, D. Crystallization mechanism and properties of high basicity steel slag-derived glass-ceramics. J. Ceram. Soc. Jpn. 2016, 124, 247-250. [CrossRef]

11. Li, H.; Tang, Z.; Li, N.; Cui, L.; Mao, X.Z. Mechanism and process study on steel slag enhancement for $\mathrm{CO}_{2}$ capture by seawater. Appl. Energy 2020, 276, 115515. [CrossRef]

12. Liu, G.; Schollbach, K.; van der Laan, S.; Tang, P.; Florea, M.V.; Brouwers, H.J.H. Recycling and utilization of high volume converter steel slag into $\mathrm{CO}_{2}$ activated mortars-The role of slag particle size. Resour. Conserv. Recycl. 2020, $160,104883$. [CrossRef]

13. Zullaikah, S.; Utomo, A.T.; Yasmin, M.; Ong, L.K.; Ju, Y.H. Ecofuel conversion technology of inedible lipid feedstocks to renewablefuel. In Advances in Eco-Fuels for a Sustainable Environment, 1st ed.; Azad, K., Ed.; Woodhead Publishing, Elsevier: Amsterdam, The Netherlands, 2019; pp. 237-276. [CrossRef]

14. Mei, H.; Zhang, C.; Yin, D. Survey of Studies on Renewable Energy Production by Microalgae. J. Wuhan Bot. Res. 2008, 26, 650-660.

15. Chisti, Y. Biodiesel from microalgae. Biotechnol. Adv. 2007, 25, 294-306. [CrossRef]

16. Sathasivam, R.; Radhakrishnan, R.; Hashem, A.; Allah, E.F.A. Microalgae metabolites: A rich source for food and medicine. Saudi J. Biol. Sci. 2019, 26, 709-722. [CrossRef]

17. Xia, A.; Sun, C.; Fu, Q.; Liao, Q.; Huang, Y.; Zhu, X.; Li, Q. Biofuel production from wet microalgae biomass: Comparison of physicochemical properties and extraction performance. Energy 2020, 212, 118581. [CrossRef]

18. Lima, S.; Villanova, V.; Grisafi, F.; Caputo, G.; Brucato, A.; Scargiali, F. Autochthonous microalgae grown in municipal wastewaters as a tool for effectively removing nitrogen and phosphorous. J. Water Process. Eng. 2020, 38, 101647. [CrossRef]

19. Jamil, N.H.; Abdullah, M.; Pa, F.C.; Mohamad, H.; Ibrahim, W.M.A.W.; Chaiprapa, J. Influences of $\mathrm{SiO}_{2}, \mathrm{Al}_{2} \mathrm{O}_{3}, \mathrm{CaO}$ and $\mathrm{MgO}$ in phase transformation of sintered kaolin-ground granulated blast furnace slag geopolymer. J. Mater. Res. Technol. 2020, 9 , 14922-14932. [CrossRef]

20. Yamamoto, T.; Osawa, K.; Asaoka, S.; Madinabeitia, I.; Liao, L.M.; Hirata, S. Enhancement of Marine Phytoplankton Growth by Steel-making Slag as a Promising Component for the Development of Algal Biofuels. ISIJ Int. 2016, 56, 708-713. [CrossRef]

21. Haraguchi, K.; Suzuki, K.; Taniguchi, A. Effects of Steelmaking Slag Addition on Growth of Marine Phytoplankton. ISIJ Int. 2003, 43, 1461-1468. [CrossRef]

22. Nakamura, Y.; Taniguchi, A.; Okada, S.; Tokuda, M. Positive Growth of Phytoplankton under Conditions Enriched with Steel-making Slag Solution. Trans. Iron Steel Inst. Jpn. 1998, 38, 390-398. [CrossRef] 
23. Yang, B.-M.; Lai, W.-L.; Chang, Y.-M.; Liang, Y.-S.; Kao, C.-M. Using desulfurization slag as the aquacultural amendment for fish pond water quality improvement: Mechanisms and effectiveness studies. J. Clean. Prod. 2017, 143, 1313-1326. [CrossRef]

24. Takahashi, T.; Yokoyama, S. Bioassay of Components Eluted from Electric Arc Furnace Steel Slag Using Microalgae Chlorella. ISIJ Int. 2016, 56, 1497-1505. [CrossRef]

25. Suzuki, M.; Yamamoto, T. Effect of Steel-making Slag Addition on Growth of the Diatom Skeletonema costatum and the Dinoflagellate Alexandrium tamarense. Tetsu-to-Hagané 2005, 91, 783-787. [CrossRef]

26. Čabanová, K.; Vlček, J.; Seidlerová, J.; Matějka, V.; Peikertová, P.; Martausová, I.; Kukutschová, J. Chemical and phase composition of metallurgical slags and their effects on freshwater green algae. Mater. Today 2018, 5, 2-10. [CrossRef]

27. Ishii, M.; Yamamoto, T.; Nakahara, T.; Takeda, K.; Asaoka, S. Effect of Carbonated Steelmaking Slag on the Growth of Benthic Microalgae. J. Iron Steel Inst. Jpn. 2013, 99, 260-266. [CrossRef]

28. Castaldello, C.; Gubert, A.; Sforza, E.; Facco, P.; Bezzo, F. Microalgae Monitoring in Microscale Photobioreactors via Multivariate Image Analysis. ChemEngineering 2021, 3, 49. [CrossRef]

29. Du, S.L.; Huang, S.L.; Zang, C.J.; Wu, M.; Gao, F.; Lin, C.; Guo, Y.; Luo, Y. Correlation research between the indicators of phytoplankton standing stock I: Chlorophyll a and biomass. J. Water Resour. Water Eng. 2011, 1, 40-44.

30. Faria, A.P.D.; Marabesi, M.A.; Gaspar, M.; França, M.G.C. The increase of current atmospheric $\mathrm{CO}_{2}$ and temperature can benefit leaf gas exchanges, carbohydrate content and growth in $\mathrm{C}_{4}$ grass invaders of the Cerrado biome. Plant Physiol. Biochem. 2018, 127, 608-616. [CrossRef]

31. Ikaw, H.; Chen, C.P.; Sikma, M.; Yoshimoto, M.; Sakai, H.; Tokida, T.; Usui, Y.; Nakamura, H.; Ono, K.; Maruyama, A.; et al. Increasing canopy photosynthesis in rice can be achieved without a large increase in water use-a model based on free-air $\mathrm{CO}_{2}$ enrichment. Glob. Chang. Biol. 2017, 24, 1321-1341. [CrossRef]

32. Yoda, K. Effects of terrestrial ecosystems on the carbon dioxide concentration in the atmosphere. Chikyukagaku 1982, 16, 78-85. [CrossRef]

33. Beruto, D.T; Botter, R. Liquid-like $\mathrm{H}_{2} \mathrm{O}$ adsorption layers to catalyze the $\mathrm{Ca}(\mathrm{OH})_{2} / \mathrm{CO}_{2}$ solid-gas reaction and to form a non-protective solid product layer at $20^{\circ}$ C. J. Eur. Ceram. Soc. 2000, 20, 497-503. [CrossRef] 